Sains Malaysiana 49(4)(2020): 729-742

http://dx.doi.org/10.17576/jsm-2020-4904-02

\title{
Baseline Study of Heavy Metal Pollution in a Tropical River in a Developing Country
}

(Kajian Peringkat Dasar Pencemaran Logam Berat di Sungai Tropika di Negara Membangun)

Tengku Nilam Baizura Tengku Ibrahim, Faridah Othman* \& Noor Zalina Mahmood

\begin{abstract}
Massive load of toxic heavy metals is discharged by human activities, as well as by natural actions, give rise to metal contamination in water body. Sg. Sembilang is one of the rivers that is receiving effluent from various sources such as landfill, industrial, residential, and agricultural runoff. In this study, the concentration of heavy metals in nine stations along the Sg. Sembilang was collected for one year period to evaluate their levels of pollution. Ten heavy metals were analyzed using inductively coupled plasma optical emission spectroscopy (ICP-OES). The mean concentrations of $\mathrm{Fe}, \mathrm{Mn}, \mathrm{Zn}, \mathrm{Al}$, and $\mathrm{Cu}$ were 3.01, 0.68, 0.29, 0.007, and $0.027 \mathrm{mg} / \mathrm{L}$ respectively, were below the National Water Quality Standards of Malaysia (NWQS), with the exception of $\mathrm{Cd}, \mathrm{Cr}, \mathrm{Pb}, \mathrm{Mg}$, and Ni. Calculated HPI based on the mean concentration of heavy metals, was found to be 6.05, that is below the critical pollution index value of 100. With respect to sampling locations, station J03 registered the highest value of 7.989. This is probably due to the location of J03 which is very near to the effluent discharge point. The analysis indicates the present scenario of water quality of $\mathrm{Sg}$. Sembilang due to the effect of effluent from the landfill material, and waste water from industry, agricultural runoff and residential area. Required steps should be taken to conserve this river from pollution, and also to lessen the environmental risk.
\end{abstract}

Keywords: Heavy metals; Heavy Metal Pollution Index (HPI); river water quality; water quality

\section{ABSTRAK}

Jumlah logam berat toksik yang dilepaskan hasil daripada aktiviti manusia, serta proses semula jadi telah menyebabkan pencemaran logam dalam badan air. Dalam kajian ini, kepekatan logam berat di sembilan stesen pensampelan di sepanjang Sg. Sembilang telah dikumpulkan selama satu tahun untuk menilai tahap pencemaran di setiap stesen. Sepuluh logam berat dianalisis menggunakan spektroskopi pelepasan optik plasma (ICP-OES) yang digabungkan secara induktif. Hasil menunjukkan kadar kepekatan Fe, $\mathrm{Mn}$, Zn, Al dan Cu masing-masing ialah 3.01, 0.68, 0.29, 0.007 dan 0.027 mg/L di bawah Piawaian Kualiti Air Negara Malaysia (NWQS), kecuali Cd, Cr, $\mathrm{Pb}, \mathrm{Mg}$ dan Ni. Berdasarkan kepekatan logam berat, nilai HPI didapati berada pada tahap 6.05 iaitu di bawah nilai indeks pencemaran kritikal, 100. Manakala berdasarkan dengan lokasi persampelan, stesen J03 mencatatkan nilai tertinggi 7.989. Ini disebabkan lokasi J03 yang sangat dekat dengan titik pelepasan efluen. Analisis ini menunjukkan senario kualiti air Sg. Sembilang kesan daripada efluen daripada bahan pelupusan sampah dan air sisa daripada industri, larian pertanian dan kawasan kediaman. Pelbagai langkah perlu diambil untuk memulihara sungai ini daripada pencemaran dan juga untuk mengurangkan risiko alam sekitar.

Kata kunci: Indeks Pencemaran Logam Berat (HPI); kualiti air; kualiti air sungai; logam berat

\section{INTRODUCTION}

River pollution is a crucial and emerging issue in most developing countries today. The amount of waste disposed of in surface water systems has increased due to massive industrial development (Naji et al. 2010). One of the main sources of environmental toxicity is the industrial waste and sewage entering the rivers and streams, putting Aquaculture and Water Quality at risk (Wu et al. 2016). Water quality is vital to mankind as it is directly related to human well - being. The main pollutants in water include the volatile organic compounds, biodegradable and recalcitrants, heavy metals, plant nutrients, suspended solids, microbial pathogens, and parasites (Ayandiran et al. 2018; Panfili et al. 2017; Wang et al. 2013). Heavy metals among the pollutants are seriously affected by the fact that they build up through the food chain and create environmental issues. Higher heavy metal concentrations can lead to damaging complex compounds that critical impact various biological processes (Ali et al. 2016; Bhuyan et al. 2017; Irzon et al. 2018). The existence of heavy metals in industrial wastewater is a significant risk to aquatic ecosystems, animals and humans. Higher concentrations of heavy metals often pose a significant threat to biota and the environment of any ecosystem (Tang et al. 2016; Xu et al. 2017). Heavy metal pollution can be a much more serious issue because they cannot be 
degraded by natural processes and continue to exist in soil and sediment from where they are rapidly released as sinks into watercourses (Paul et al. 2017; Xu et al. 2017). Heavy metals are generated mostly from natural and human activity sources and can accumulate in sediments, with serious environmental consequences both for local communities and for the quality of the river. The term 'heavy metals' refers to the group of metals and metalloids with a fairly high atomic weight and a specific gravity of $\leq 5 \mathrm{~cm} 3$ (Aghoghovwia et al. 2018; Paul et al. 2017; Rosli et al. 201; Wu et al. 2017; Xu et al. 20178). Due to their persistence, bioaccumulation and high toxicity, heavy metal pollutants of all different kinds have gotten a lot of attention in recent years (Bukar et al. 2016). Some heavy metals including chromium, nickel, iron, zinc, copper, and manganese are vital for biological systems in the human body that acts as both structural and catalytic components of proteins and enzymes; while others including cadmium, mercury, lead, and arsenic are widely known to be extremely toxic and contain carcinogenic metalloids which can lead to cancer in the skin, lungs and urinary tract (Rajeshkumar et al. 2018; Shaari et al. 2016). Essential heavy metals, but again, become harmful when their concentration exceeds acceptable limits and toxic metals are extremely toxic though at low doses (Aghoghovwia et al. 2018; Chen et al. 2018; Gafur et al. 2018).

Heavy metal contamination is not a modern phenomenon that arises from industrial development that started whenever people began to process ores. Since then, the use of metals and their environmental effects have sped up, with a significant increase (Gao 2018). Most heavy metals exist in different sources into the river, which can be either natural by degradation and corrosion or anthropogenic (Nguyen et al. 2016; Paul et al. 2017). Metal concentrations differ in the natural environment, both within and between different types of rock. In the surrounding environment, weathering and erosion processes release metals. Human resources relate primarily to agriculture, transportation and industrial activities (Irzon et al. 2018; Meng et al. 2016; Wang et al. 2017). Industries that ascribe heavy metals to river water typically include metal industries, paints, pigments, varnishes, pulp and paper, tannery, distillery, rayon, cotton textiles, rubber, thermal power plants, steel plants, galvanization of iron products and mining industries and also the unsystematic use of pesticides and fertilizers in agricultural fields (Paul et al. 2017). Due to its toxicity, persistence and bioaccumulative nature, the prevalent contamination of the river by heavy metal ions is of great concern. This type of heavy metal pollution can result in major risks to public health through the food chain, particularly from drinking water, which can damage the entire biological environment (Fawaz et al. 2016; Singh \& Kumar 2017; Zhang et al. 2016). In recent years, heavy metal pollution has occurred in several countries. Heavy metal concentrations in many other famous rivers' water is higher than the regulations. Additionally, pollution is so much more severe in many small rivers (Kandler et al. 2017).

In correlation with government growth policies, Malaysia is currently experiencing a neverending rapid change in land use. Among Malaysia's states, Selangor was the fastest growing and heavily populated state with 3.9 million residents in 2000. The land used for agriculture in Selangor has widened as oil palm plantations have increased. Industrialization policy has led directly to state developments in urbanization, trade, and infrastructure. The increase in land used for both urban and agricultural sectors has led to natural and wetland forest clearing. Modifications in rapid land use have been shown to cause drastic environmental deterioration in various environmental compartments such as forests, wetlands, and aquatic ecosystems. The riverine ecosystem in Malaysia is of particular relevance as the river supplies about 98 percent of the country's water requirements. River water pollution therefore poses a genuine public health risk. The monitoring of river water quality is under the liability of the Department of Environment (DOE), Malaysia (Harguinteguy et al. 2016). Heavy Metal Pollution Index (HPI) has been broadly applied by various researchers for the comparative assessment of metal contamination adjacent current water quality guidelines (Majhi \& Biswal 2016). Over the year, there have been numerous studies on heavy metal content in rivers in Malaysia including Sg. Baleh in Sarawak (Chai et al. 2018), Sg. Langat Basin, Selangor (Kadhum et al. 2015), Sg. Kepayang, Perak (Affandi \& Ishak 2018), Sg. Linggi, Negeri Sembilan (Khalaf et al. 2018), Sg. Selangor, Selangor (Othman et al. 2018), Sg. Terengganu, Terengganu (Sukri et al. 2018) as well as Sg. Liwagu and Sg. Mansahaban in Sabah (Tair \& Eduin 2018). However, until now there is limited information on heavy metal content in Sg. Sembilang, Kuala Selangor, Selangor which received various pollutants from upstream to downstream of the river. The purpose of this study was to analyze the metal concentrations in the Sg. Sembilang from ten different locations along the river. The river water samples were analyzed to investigate the concentrations of ten heavy metals: aluminium (Al), magnesium $(\mathrm{Mg})$, manganese $(\mathrm{Mn})$, copper $(\mathrm{Cu})$, iron $(\mathrm{Fe})$, nickel $(\mathrm{Ni})$, chromium $(\mathrm{Cr})$, cadmium $(\mathrm{Cd})$, lead $(\mathrm{Pb})$ and zinc $(\mathrm{Zn})$.

\section{MATERIALS AND METHODS}

\section{STUDY AREA}

The study area is Sg. Sembilang, lies in Sg. Selangor basin, located within Kuala Selangor, Selangor, Malaysia. The catchment area is about $633.79 \mathrm{~m} 3 \mathrm{~s}-1$. The river length is approximately $7840 \mathrm{~m}$ long and $16 \mathrm{~m}$ wide and generally lie in the longitude-latitude quadrangle of 101.37E, $3.19 \mathrm{~N}$ and $101.30 \mathrm{E}, 3.19 \mathrm{~N}$. There are a number of catchment areas located along the Sg. Sembilang that includes Ladang Bukit Panjong, Ladang Athlone, Ladang Choh, Ladang Jeram and Ladang Bukit Cherakah. 
The economy of Sg. Sembilang is based predominantly on agriculture (palm oil plantation) and primary industries. At the upstream of the river lies Jeram Sanitary Landfill which has been built since 1997. Along the river from upstream until before the downstream is covered with palm oil plantation, and there is also a small residential area with a population of around 9500 people. Other than that, there is a small industrial area in downstream of the river which is a factory that process rubber, plastic and timber. At the same time, however, this river is also a major source of income for local people, namely fisheries and aquaculture activities. In addition, Pantai Remis, located in the downstream river, is also a major tourist destination in Kuala Selangor, Selangor. Located south of the river is the tourist attraction and place for seafood enthusiast, Pantai Remis (Figure 1).
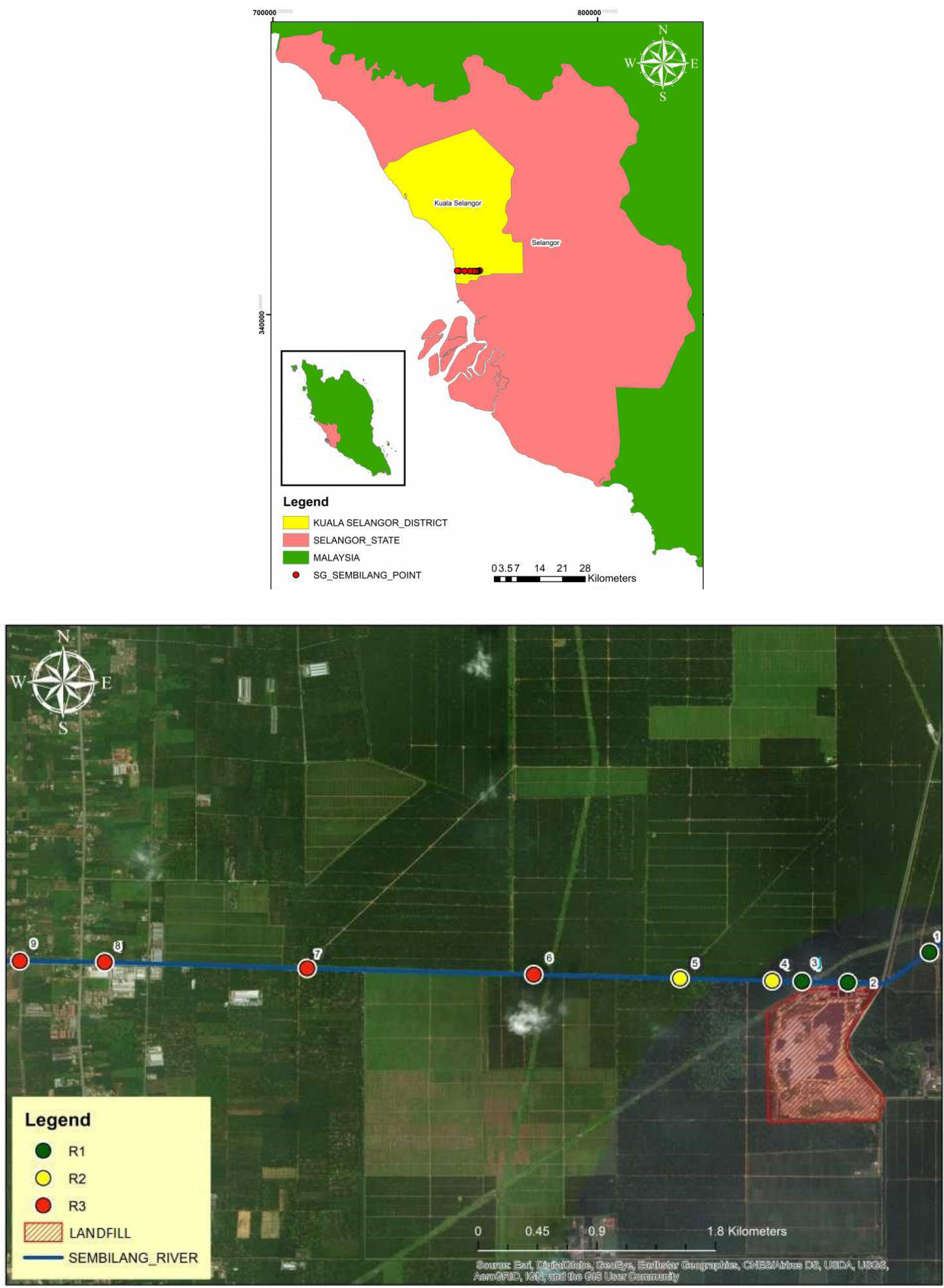

FIGURE 1. Study area and motoring stations locations 


\section{DATA COLLECTION}

Water quality sampling was conducted to know the present water quality of $\mathrm{Sg}$. Sembilang. Water samples were collected from 9 sampling stations every two months from September 2015 to September 2016. The distance of $\mathrm{Sg}$. Sembilang is approximately $7 \mathrm{~km}$. The samples were analyzed and the results were recorded. To reach each of the sampling stations, it was necessary to drive using vehicles that were capable of traversing muddy terrain and broken tracks. Locations of the sampling stations are presented in Table 1.

TABLE 1. Location point of study area

\begin{tabular}{|c|c|c|c|c|}
\hline \multirow{2}{*}{$\begin{array}{l}\text { Location } \\
\text { Point }\end{array}$} & \multirow[b]{2}{*}{ Status } & \multicolumn{2}{|c|}{ Coordinate } & \multirow[b]{2}{*}{ Remarks } \\
\hline & & $\begin{array}{l}\text { Latitude } \\
\text { (Deg.) }\end{array}$ & $\begin{array}{l}\text { Longitude } \\
\text { (Deg.) }\end{array}$ & \\
\hline J01 & \multirow{2}{*}{ Upstream } & 3.196 & 101.373 & $\begin{array}{l}\text { Sg Sembilang } \\
\text { Upstream }\end{array}$ \\
\hline J02 & & 3.194 & 101.370 & $\begin{array}{l}500 \mathrm{~m} \text { from landfill } \\
\text { area }\end{array}$ \\
\hline J03 & \multirow{7}{*}{ Downstream } & 3.194 & 101.360 & $\begin{array}{l}\text { Downstream of } \\
\text { Sembilang River }\end{array}$ \\
\hline $\mathrm{J} 04$ & & 3.194 & 101.353 & Palm oil plantation site \\
\hline $\mathrm{J} 05$ & & 3.195 & 101.330 & $\begin{array}{c}\text { School/small residential } \\
\text { area }\end{array}$ \\
\hline J06 & & 3.195 & 101.326 & Factories \\
\hline $\mathrm{J} 07$ & & 3.195 & 101.320 & Industrial zone \\
\hline $\mathrm{J} 08$ & & 3.195 & 101.315 & Highway culvert \\
\hline J09 & & 3.195 & 101.311 & $1 \mathrm{~km}$ to the sea \\
\hline
\end{tabular}

\section{HEAVY METAL ANALYSIS}

Water The preparation of the samples was completed after USEPA-2007. $20 \mathrm{~mL}$ of each sample was placed in a $50 \mathrm{~mL}$ centrifuge tube before adding $0.4 \mathrm{~mL}$ of nitric acid $(1+1)$ to the samples. The centrifuge tubes are then placed for $2 \mathrm{~h}$ in a water bath at $85^{\circ} \mathrm{C}$. In order to cool down the solution until it reached room temperature, the centrifuge tubes were then removed from the water bath. Water samples are then filtered using a syringe filtration unit using a $0.45 \mu \mathrm{m}$ cellulose acetate membrane filter. This was done to obtain dissolved metal while preventing the spectrometry instrument from being blocked during analysis. A sample of quality control (QC) was also prepared to monitor recovery according to the guidelines of USEPA-2010. The reproducibility and recovery of metal analysis in water samples increased with adequate quantities of metals.

Digested samples were examined by an ICP optical atomic emission spectrometry to most metal concentrations. For this evaluation of water quality, total dissolved elements and main ions concentrations which were analyzed, includes: aluminium (Al), magnesium $(\mathrm{Mg})$, manganese $(\mathrm{Mn})$, copper $(\mathrm{Cu})$, iron $(\mathrm{Fe})$, nickel $(\mathrm{Ni})$, chromium $(\mathrm{Cr})$, cadmium $(\mathrm{Cd})$, lead $(\mathrm{Pb})$, and zinc (Zn). ICP multi-element standard solution was used as the standard solution. To float the calibration curves, five standards were examined. The wavelengths and the corresponding detection limit (LOD) of each component, including the quantitative limit. The statistical variances between the sampling stations were conducted at a significant $\mathrm{p}<0.05$ level using the Kruskal - Wallis test. The Tukey's test was used to compare the mean values. Environmental risk assessment was performed by equating the index of heavy metal pollution (HPI) in the area of study. The HPI has been obtained using (1)

$$
\mathrm{HPI}=\sum \text { QiWi }
$$

where Wi is the score weight for each parameter preferred for heavy metal assessment and is directly related to the suggested standard, i.e. the highest allowable amount for heavy metals' drinking water ( $\mathrm{Si}$ ). The rating is a value between zero and one. Qi, is the Subindex of the $\mathrm{i}^{\text {th }}$ parameter and was calculated using (2).

$$
\mathrm{Qi}=\frac{(\mathrm{Mi}-\mathrm{Ii}) \times 100}{(\mathrm{Si}-\mathrm{Ii})}
$$

where $\mathrm{Mi}$ is the measured value of the $\mathrm{i}^{\text {th }}$ parameter; $\mathrm{Ii}$ is the desired maximum value (ideal) of the $i^{\text {th }}$ parameter; and $\mathrm{Si}$ is the suggested $\mathrm{i}^{\text {th }}$ parameter standard. The crucial index of pollution is 100 . The $\mathrm{Si}$ and Ii values have been taken from the Malaysian national water quality standard for the current study. 


\section{RESULTS AND DISCUSSION}

The heavy metal of river water samples was collected and analyzed based on their concentration. Prior to the data analysis, data were first checking for normality and analysis shows that all data is not distributed normally among the sampling point. Hence, this analysis adopts Kruskal-Wallies test, that is a non-parametric test. From the Kruskal-Wallies test, only Mg showed significant difference among the stations with $\mathrm{p}$ value of 0.007 . This indicates a fairly strong relationship between concentration of $\mathrm{Mg}$ and sampling point along the river. Follow up tests were run to calculate pairwise differences among sampling stations. The outcome of these tests indicates a significant difference between sampling stations

Large quantities of heavy metals deteriorate the aquatic environment causing a momentous challenge and exposure to human health and environment. The concentrations of Aluminum (Al), Magnesium ( $\mathrm{Mg}$ ), Manganese $(\mathrm{Mn})$, Copper $(\mathrm{Cu})$, Iron $(\mathrm{Fe})$, Zinc $(\mathrm{Zn})$, Cadmium (Cd), Nickel (Ni), Chromium (Cr), and Lead $(\mathrm{Pb})$ were analyzed. The results of heavy metal concentrations in surface waters of Sg. Sembilang are shown in Table 2 and Figure 2. The average concentration of studied metals in water followed a decreasing order of $\mathrm{Mg}>\mathrm{Al}>\mathrm{Fe}>\mathrm{Mn}>\mathrm{Zn}>\mathrm{Cu}>\mathrm{Ni}>\mathrm{Cr}>\mathrm{Pb}>\mathrm{Cd}$. Only the higher value of heavy metal from standard level are further elaborated.

Al concentration in water samples from $\mathrm{Sg}$. Sembilang ranged from 0.0736 to $23.16 \mathrm{mg} / \mathrm{L}$ with a mean of $5.862 \pm 2.111 \mathrm{mg} / \mathrm{L}$ (Table 2). Mean Al levels in study area were above National Water Quality Standard (NWQS) permissible limit of $0.06 \mathrm{mg} / \mathrm{L}$ for raw water. Earlier study conducted at $\mathrm{Sg}$. Sembilang reported $\mathrm{Al}$ concentrations that ranged from 0.48 to $1.5 \mathrm{mg} / \mathrm{L}$ (Bhuyan et al. 2017). The existence of aluminum ions in river water due to the landfill waste. As the effluent from the landfill is disposed near to J03, the value increases to the max value at station J03 with average value of 8.9338 $\mathrm{mg} / \mathrm{L}$ that was exceeded the permissible limit $(0.06$ $\mathrm{mg} / \mathrm{L}$ ) of NWQS. After that, the average value decreases up to the station J09 with Al concentration $2.9584 \mathrm{mg} / \mathrm{l}$.

Leaching of $\mathrm{Al}$ to rivers can be reduced by modern, controlled farmland drainage techniques (Sutela \& Vehanen 2017). Al concentration in surface water differ with $\mathrm{pH}$ of the water. High levels of $\mathrm{Al}$ in natural water only occur when the $\mathrm{pH}$ is below 5 . The concentration in most surface water is very low because the $\mathrm{pH}$ of approximately $95 \%$ of natural water ranges from 6 to 9 (Zuziak \& Jakubowska 2017). This is the same as Al concentration in $\mathrm{Sg}$. Sembilang where at $\mathrm{pH}$ in the range of $6.573-3.832, \mathrm{Al}$ concentration increases from $\mathrm{J} 01$ to $\mathrm{J} 05$ and it decreases to $\mathrm{J} 09$ where the $\mathrm{pH}$ of the river in this area is increasing. Study also found that $\mathrm{Al}$ concentrations in coastal area typically range from 0.5 to $2 \mu \mathrm{g} / \mathrm{L}$ and 0.008 to $0.68 \mu \mathrm{g} / \mathrm{L}$ in the open ocean. This is impressive given that many coastal sites are signatory to point source or diffuse $\mathrm{Al}$ inputs including urban runoff and general industrial inputs and also atmospheric aluminum deposition into surface water discharges associated with $\mathrm{Al}$ and $\mathrm{Al}$ production activities (Angel et al. 2015). This can be illustrated by the concentration of $\mathrm{Al}$ at $\mathrm{J} 09$ with $2.983 \mathrm{mg} / \mathrm{L}$ where the station is located a few meters from the coastal area of Pantai Remis. The $\mathrm{Al}$ concentration at this station is the lowest compared to the other nine stations.

In most forms of life, copper $(\mathrm{Cu})$ is an essential component. However, $\mathrm{Cu}$ may become harmful at high bioavailable concentrations. With its use in industry and agriculture (e.g. $\mathrm{Cu}$ consist of fungicides and herbicides), $\mathrm{Cu}$ leaked into the environment from these sources is substantial (Bui et al. 2016). In the environment, $\mathrm{Cu}$ 's fate depends on changes in physical and chemical speciation properties ( $\mathrm{pH}$, redox, ionic strength) and relationships with environmental components (mineral or organic particles) (Guinoiseau et al. 2018). The concentration of $\mathrm{Cu}$ was greater than $0.02 \mathrm{mg} / \mathrm{L}$, indicating Class-V in National Water Quality Standards of Malaysia. $\mathrm{Cu}$ can occur in all three possible forms, i.e. dissolved, colloidal and particulate, in freshwater systems (Borah et al. 2018). In the present study, $\mathrm{Cu}$ content ranged from $0.0198-0.131 \mathrm{mg} / \mathrm{L}$ (Table 2). At J01, that is located at the upstream of the river, $\mathrm{Cu}$ content was high and may be due to the soil, agriculture and geological formations. The high content of $\mathrm{Cu}$ might be due to the increase in temperature, which increases the release of $\mathrm{Cu}$ ions from the sediments and thus rises the total content of $\mathrm{Cu}$ in the water column (Zhang et al. 2018). Cu was lowest at $\mathrm{J} 09$ with a value of $0.0198 \mathrm{mg} / \mathrm{L}$. The result shows that the concentration of dispersion varies due to several factor affected on upstream, landfill and downstream stations. The upstream station may be affected by soil, agricultural and geological formation, while the landfill and downstream stations may be affected by effluent and industrial factors.

$\mathrm{Mn}$ is typical elements in the earth's crust and can be discovered in a length of minerals in rocks and soils (Essington 2015). Mn is extremely responsive to redox environment and somewhat mobile in the aquatic environment and dictate at lower $\mathrm{pH}$ (Fremion et al. 2016). The concentrations of Mn vary from station to station along the river. The results show that all stations exhibit more than $0.2 \mathrm{mg} / \mathrm{L}$ of $\mathrm{Mn}$ concentration that represent Class V of NWQS of Malaysia. The concentrations of $\mathrm{Mn}$ ranged between 0.015 and 1.685 $\mathrm{mg} / \mathrm{L}$. These concentrations of Mn increased gradually from $\mathrm{J} 01$ to $\mathrm{J} 05$, then decreased at $\mathrm{J} 07$ and $\mathrm{J} 08$. After the landfill station, the values increase at downstream stations. The distribution of the concentration is not caused by the landfill effect, it might be from other sources such as soil and agricultural patterns for the upstream stations and industrial effect for the downstream stations of $\mathrm{Sg}$. Sembilang. Mn do not necessarily pose a health risk to humans (Nguyen et al. 2016). Mn can be assimilated by aquatic organisms mainly under its ionic form $\mathrm{Mn} 2+$, 
as an essential nutrient at low concentrations. However, it can be harmful to aquatic biota as a toxic element with LC50 (Lethal Concentrations) in the $\mathrm{mg} / \mathrm{L}$ order of magnitude. It is important to note that the chronic criteria for the safety of aquatic biota is normally range from 1 to $2 \mathrm{mg} / \mathrm{L}$. However, at high concentration, Mn can also present as a protection facing more toxic substances (Superville et al. 2018).

Natural waters encompass differential quantities of iron confide on different criteria. The main elements of interest in the aquatic environment are ferrous and ferric ions. Fe normally occurs in fresh water bodies in either soluble ferrous ion $(\mathrm{Fe} 2+)$ or insoluble ion $(\mathrm{Fe} 3$ +) (Sarkar \& Shekhar 2018). The analysis for ten river water samples showed Fe concentration in all ten stations beyond the permissible limit of NWQS $(1 \mathrm{mg} / \mathrm{L})$. The Fe concentration in these samples ranged from 1.667 to
$4.623 \mathrm{mg} / \mathrm{L}$ (Table 2). Figure 2 for mean Fe concentration in samples taken obtained from the study area illustrates the fact that most of the study area high Fe concentration in surface water (more than $1 \mathrm{mg} / \mathrm{L}$ ) with the highest Fe concentration site situated downstream of Sg. Sembilang in J03. This has also been detected for the river water samples with concentration of Fe declining downstream of the river. It first huge fluctuation in Fe concentration in river water was reported in sample from J03, near to the landfill, which is known for effluent discharge into the river. On the other hand, in locations downstream of Sg. Sembilang, low levels of Fe are reported. Here, the sampling stations were much closer to the industrial area and residential area and it could therefore be stated that the leakage of $\mathrm{Fe}$ in these locations resulted from localized anthropogenic outlets (industrial and residential waste water).

TABLE 2. Statistical summary of heavy metals in water samples from Sg. Sembilang (in mg.1-1)

\begin{tabular}{|c|c|c|c|c|c|c|c|c|c|c|c|}
\hline $\begin{array}{l}\text { Heavy } \\
\text { metal }\end{array}$ & $\begin{array}{l}\text { Statistical } \\
\text { parameter }\end{array}$ & $\begin{array}{c}\text { NWQS } \\
\text { (Class I-V) }\end{array}$ & J01 & J02 & J03 & J04 & J05 & J06 & J07 & J08 & J09 \\
\hline \multirow[t]{3}{*}{$\mathrm{Fe}$} & Mean & & 1.667 & 2.736 & 4.533 & 3.991 & 2.822 & 3.016 & 2.493 & 2.289 & 1.927 \\
\hline & Median & 1 & 1.554 & 2.736 & 4.224 & 3.436 & 2.025 & 1.188 & 1.082 & 0.950 & 0.612 \\
\hline & $\mathrm{SD}$ & & 0.703 & 1.235 & 2.969 & 2.618 & 2.583 & 3.831 & 3.158 & 2.869 & 2.488 \\
\hline \multirow[t]{3}{*}{$\mathrm{Al}$} & Mean & & 6.058 & 6.271 & 8.934 & 8.587 & 5.264 & 5.667 & 4.099 & 3.082 & 2.958 \\
\hline & Median & $0.06-0.5$ & 6.163 & 5.515 & 7.780 & 7.029 & 4.835 & 3.360 & 2.438 & 1.881 & 1.166 \\
\hline & $\mathrm{SD}$ & & 4.751 & 5.245 & 7.872 & 5.904 & 4.691 & 6.701 & 4.738 & 3.309 & 4.307 \\
\hline \multirow[t]{3}{*}{$\mathrm{Mg}$} & Mean & & 8.660 & 10.818 & 14.900 & 15.160 & 21.048 & 20.299 & 18.666 & 21.020 & 22.857 \\
\hline & Median & 150 & 8.378 & 8.362 & 13.012 & 14.884 & 17.420 & 15.181 & 14.227 & 18.708 & 21.060 \\
\hline & $\mathrm{SD}$ & & 4.725 & 8.207 & 7.050 & 4.589 & 10.356 & 10.041 & 8.873 & 8.071 & 9.948 \\
\hline \multirow[t]{3}{*}{$\mathrm{Zn}$} & Mean & & 0.133 & 0.194 & 0.173 & 0.529 & 0.185 & 0.229 & 0.277 & 0.268 & 0.260 \\
\hline & Median & $2-5$ & 0.113 & 0.098 & 0.157 & 0.241 & 0.165 & 0.260 & 0.262 & 0.268 & 0.244 \\
\hline & $\mathrm{SD}$ & & 0.072 & 0.230 & 0.107 & 0.701 & 0.096 & 0.086 & 0.135 & 0.115 & 0.280 \\
\hline \multirow[t]{3}{*}{$\mathrm{Cu}$} & Mean & & 0.032 & 0.023 & 0.026 & 0.041 & 0.024 & 0.031 & 0.022 & 0.021 & 0.020 \\
\hline & Median & $0.02-0.2$ & 0.002 & 0.002 & 0.006 & 0.037 & 0.005 & 0.009 & 0.0003 & 0.002 & 0.002 \\
\hline & SD & & 0.050 & 0.034 & 0.038 & 0.036 & 0.037 & 0.043 & 0.037 & 0.033 & 0.032 \\
\hline \multirow[t]{3}{*}{$\mathrm{Mn}$} & Mean & & 0.497 & 0.568 & 0.792 & 0.813 & 0.804 & 0.793 & 0.584 & 0.705 & 0.560 \\
\hline & Median & $0.1-0.2$ & 0.488 & 0.460 & 0.821 & 0.730 & 0.715 & 0.738 & 0.402 & 0.522 & 0.554 \\
\hline & SD & & 0.205 & 0.366 & 0.422 & 0.384 & 0.374 & 0.497 & 0.564 & 0.552 & 0.423 \\
\hline \multirow[t]{3}{*}{$\mathrm{Cr}$} & Mean & & 0.005 & 0.004 & 0.008 & 0.009 & 0.006 & 0.008 & 0.005 & 0.007 & 0.006 \\
\hline & Median & $0.05-0.1$ & 0.004 & 0.003 & 0.009 & 0.012 & 0.005 & 0.005 & 0.004 & 0.008 & 0.006 \\
\hline & SD & & 0.005 & 0.004 & 0.006 & 0.006 & 0.005 & 0.007 & 0.004 & 0.007 & 0.004 \\
\hline \multirow[t]{3}{*}{$\mathrm{Cd}$} & Mean & & 0.001 & 0.002 & 0.002 & 0.002 & 0.002 & 0.001 & 0.002 & 0.002 & 0.001 \\
\hline & Median & 0.01 & 0.800 & 0.600 & 0.900 & 0.900 & 0.900 & 0.900 & 1.500 & 0.900 & 1.100 \\
\hline & $\mathrm{SD}$ & & 0.003 & 0.003 & 0.002 & 0.003 & 0.002 & 0.002 & 0.002 & 0.002 & 0.002 \\
\hline \multirow[t]{3}{*}{$\mathrm{Pb}$} & Mean & & 0.004 & 0.003 & 0.004 & 0.011 & 0.005 & 0.004 & 0.003 & 0.002 & 0.003 \\
\hline & Median & $0.05-5$ & 0.002 & 0.001 & 0.001 & 0.010 & 0.001 & 0.002 & 0.0005 & 0.000 & 0.001 \\
\hline & SD & & 0.006 & 0.006 & 0.006 & 0.011 & 0.008 & 0.006 & 0.006 & 0.004 & 0.005 \\
\hline \multirow[t]{3}{*}{$\mathrm{Ni}$} & Mean & & 0.010 & 0.010 & 0.018 & 0.021 & 0.016 & 0.017 & 0.012 & 0.014 & 0.012 \\
\hline & Median & $0.05-9$ & 0.008 & 0.010 & 0.017 & 0.019 & 0.015 & 0.019 & 0.010 & 0.014 & 0.011 \\
\hline & $\mathrm{SD}$ & & 0.006 & 0.006 & 0.009 & 0.005 & 0.006 & 0.010 & 0.010 & 0.010 & 0.008 \\
\hline
\end{tabular}


Zinc (Zn) plays an important role in many biological processes and is an vital trace element for passable plant growth and procreation and for the health of animals and humans. (Guinoiseau et al. 2018). $\mathrm{Zn}$ is discovered in surface and groundwater and reaches the natural environment from various sources including mine drainage, industrial and municipal waste, urban runoff and, in particular, soil particle degradation featuring $\mathrm{Zn}$. As per the Food and Agricultural Organization (FAO) and to World Health Organization (WHO) drinking water containing $\mathrm{Zn}>3 \mathrm{mg} / \mathrm{L}$ appears to be opalescent, evolves a greasy film when cooked and has an unwanted astringent taste (Noulas et al. 2018).

Average $\mathrm{Zn}$ concentrations in water samples collected at ten stations in Sg. Sembilang over the study period are presented in Figure 2 and Table 2. No significant difference are observed between sampling stations. $\mathrm{Zn}$ concentration in water samples from $\mathrm{Sg}$. Sembilang ranged from 0.133 to $0.640 \mathrm{mg} / \mathrm{Lin}$ stations $\mathrm{J} 01$ and J03, respectively, with a mean of $0.2884 \pm 0.1645$ $\mathrm{mg} / \mathrm{L}$. Mean Zn levels in study area were below National Water Quality Standard (NWQS) permissible limit of 0.4 $\mathrm{mg} / \mathrm{L}$ for raw water except for station J03 and J05. The higher concentration of $\mathrm{Zn}$ at $\mathrm{J} 03$ can be attributed to the landfill effluent. It can also be derived from Table 2 that the concentrations of this metal measured in the water sample of J04 were generally higher than the levels issued by NWQS $(0.4 \mathrm{mg} / \mathrm{L})$ as well as at station J05 where the concentration were also exceeding the permissible level with $0.529 \mathrm{mg} / \mathrm{L}$. The slightly high $\mathrm{Zn}$ values for J05 can be attributed to the presence of palm oil plantation along the river which is the fertilizers and pesticides used for the plantation.

$\mathrm{Zn}$ occurs naturally in water, but the concentrations of $\mathrm{Zn}$ increase abnormally due to the addition of $\mathrm{Zn}$ by human activities. This is showed by $\mathrm{Zn}$ concentrations at $\mathrm{J} 01$ which is the lowest concentrations of $\mathrm{Zn}$ among ten other sampling stations. Studies have shown that some soils are highly polluted with $\mathrm{Zn}$ and are discovered in locations where $\mathrm{Zn}$ has to be extracted or polished or where wastewater sludge from industrial areas is used as a plant food (Ismail et al. 2013). Sg. Sembilang that passing palm oil plantation could carry with it the $\mathrm{Zn}$. During the treatment process, the metal can enter the water and also some corrosion and joint dissolution can be the possible source of $\mathrm{Zn}$ leeching into the water (Rahmanian et al. 2015). This can be seen in Figure 2 where $\mathrm{Zn}$ concentration increased from J01 to J03 and J05 where recorded the highest value and decreased to J09 which is located downstream of the river

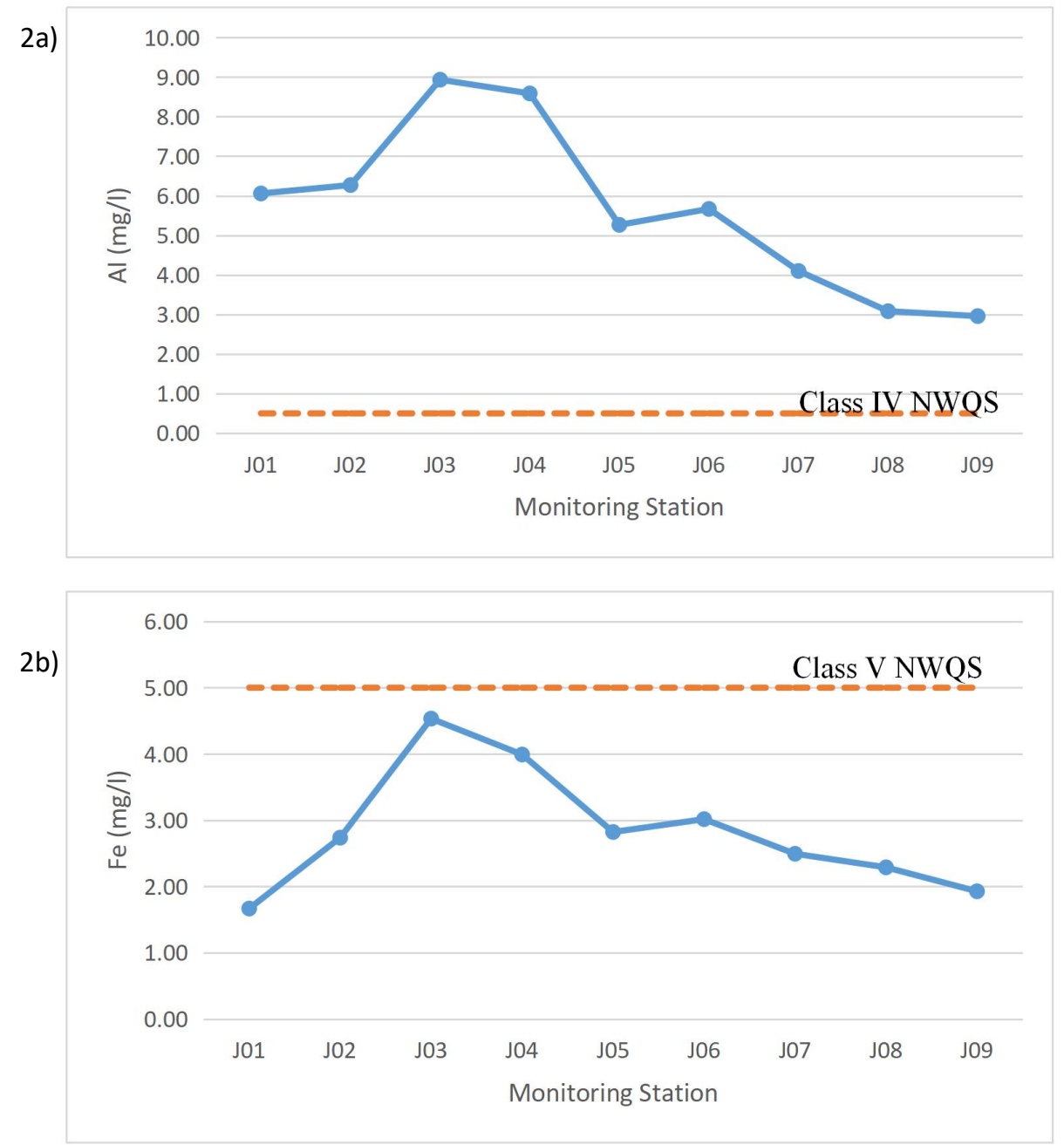


2c)

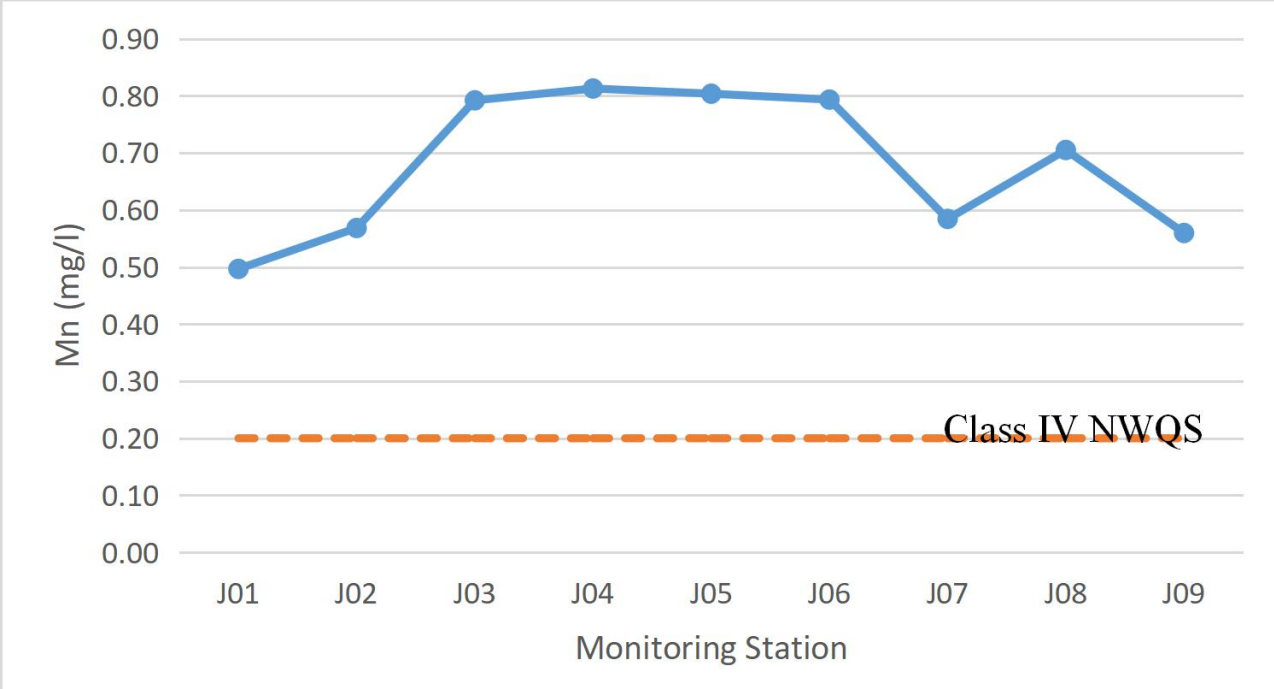

2d)

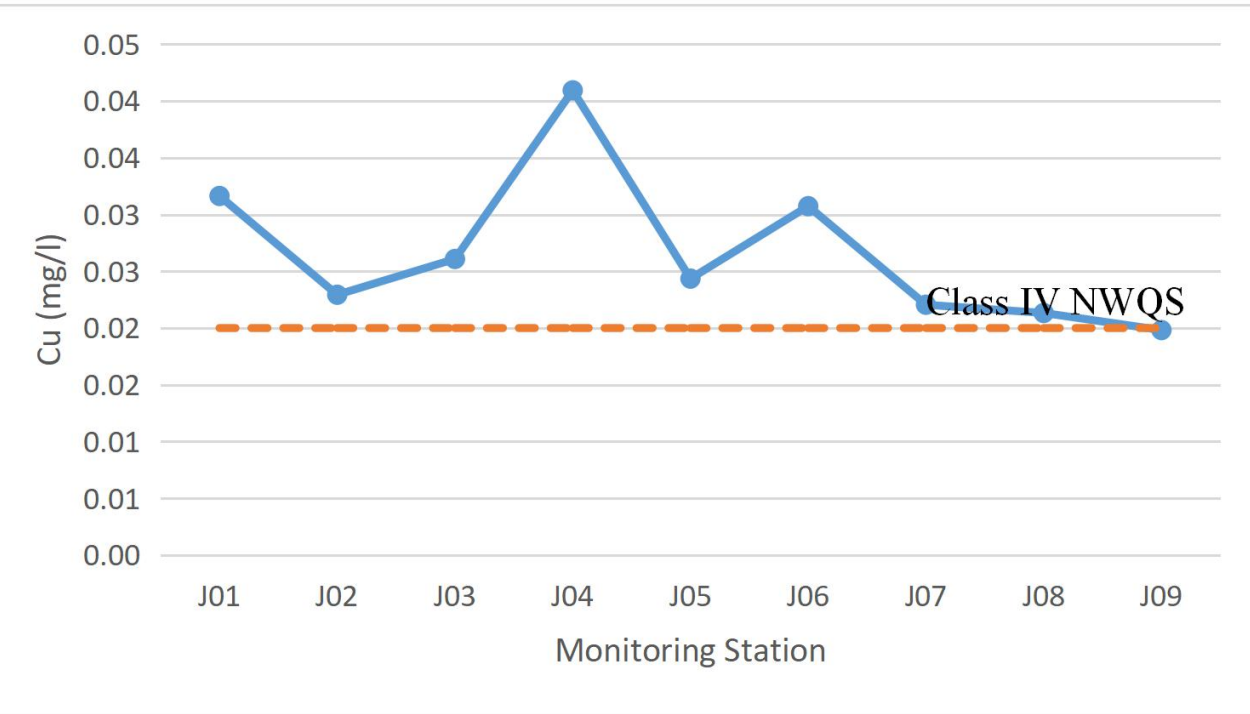

2e)

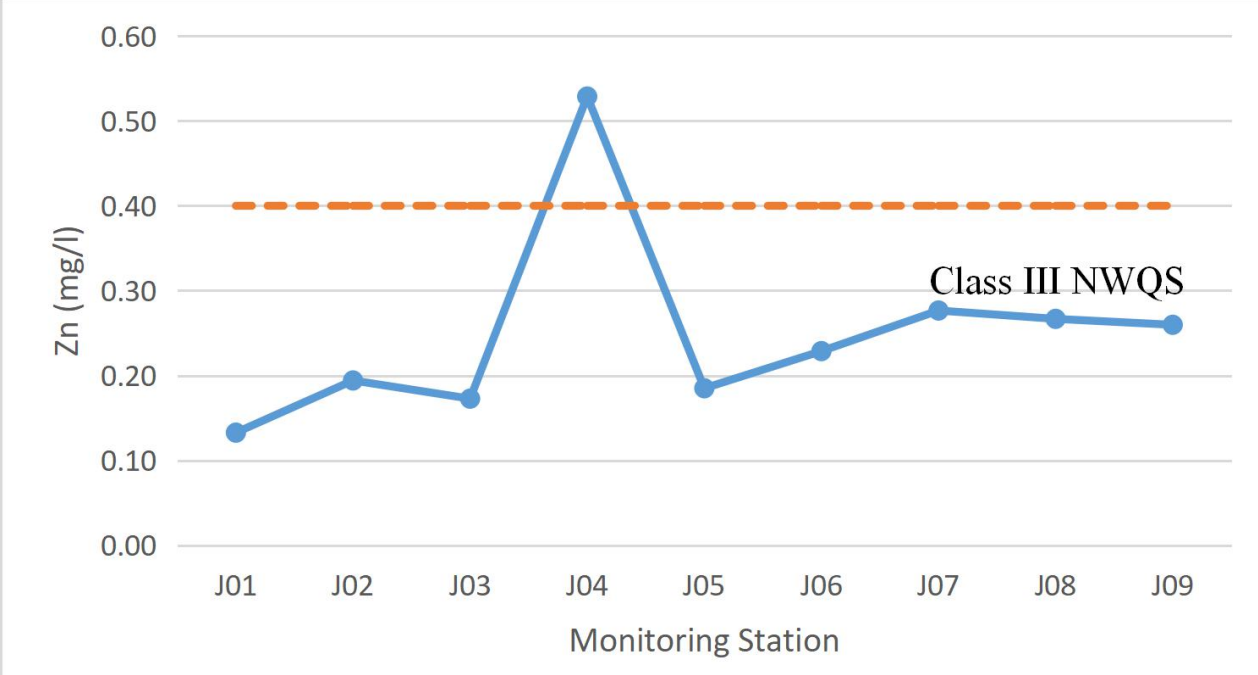




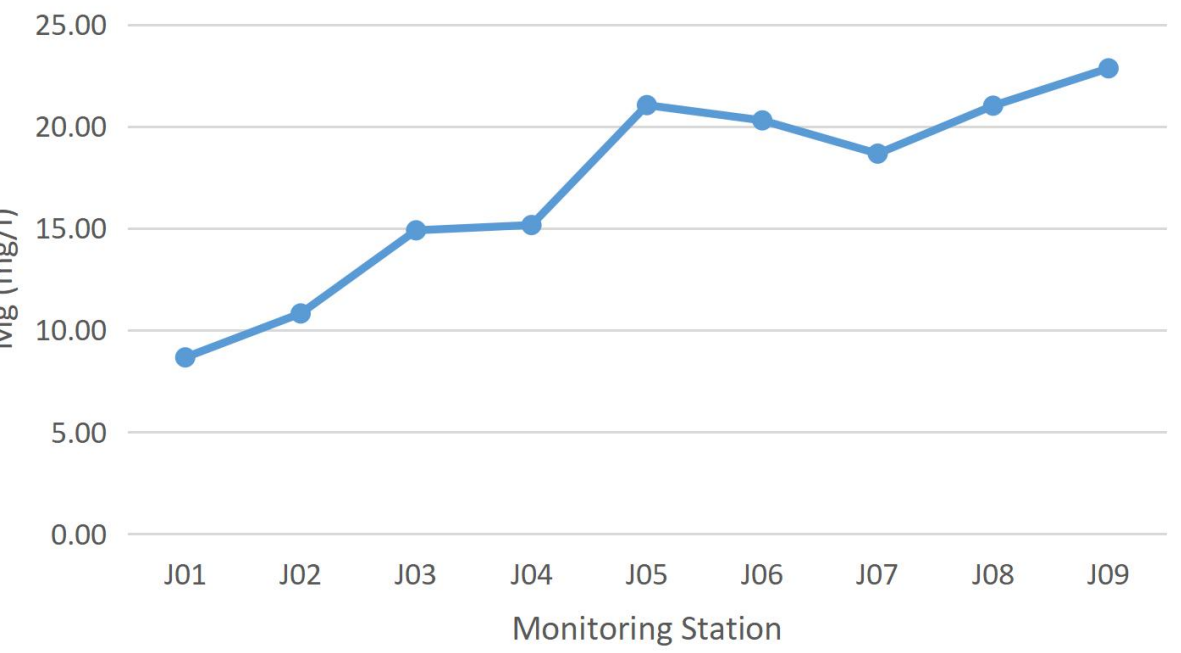

2g)

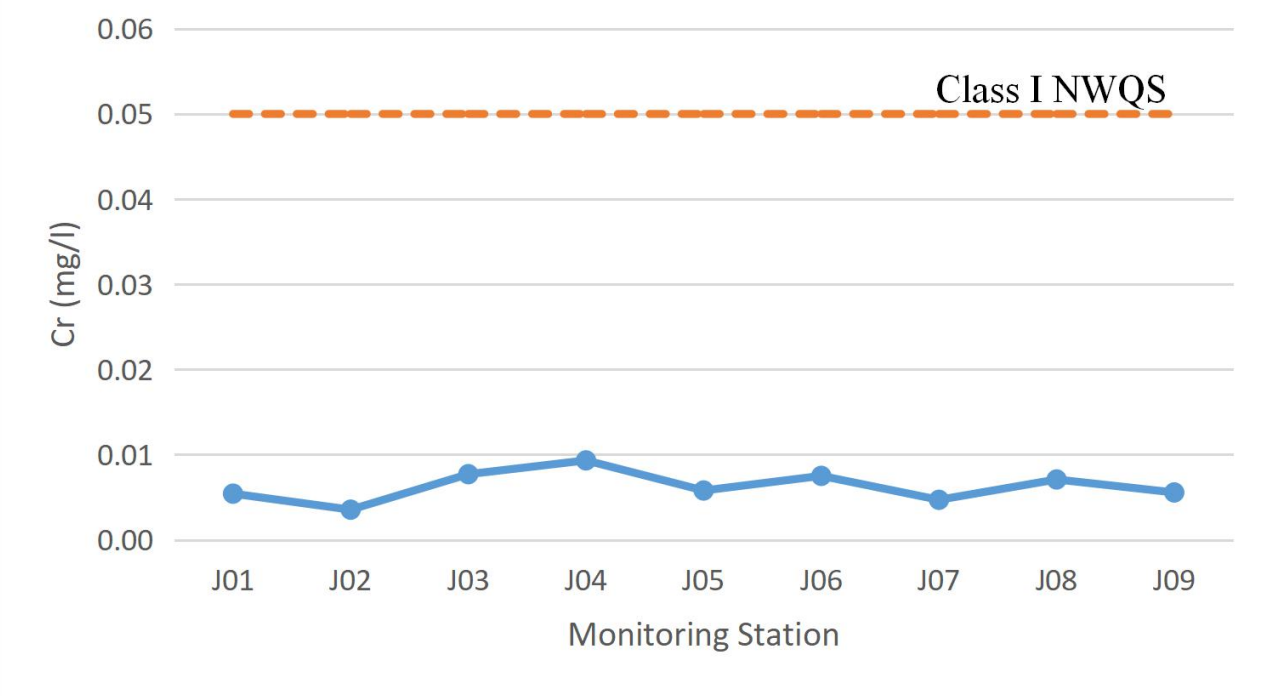

2g)

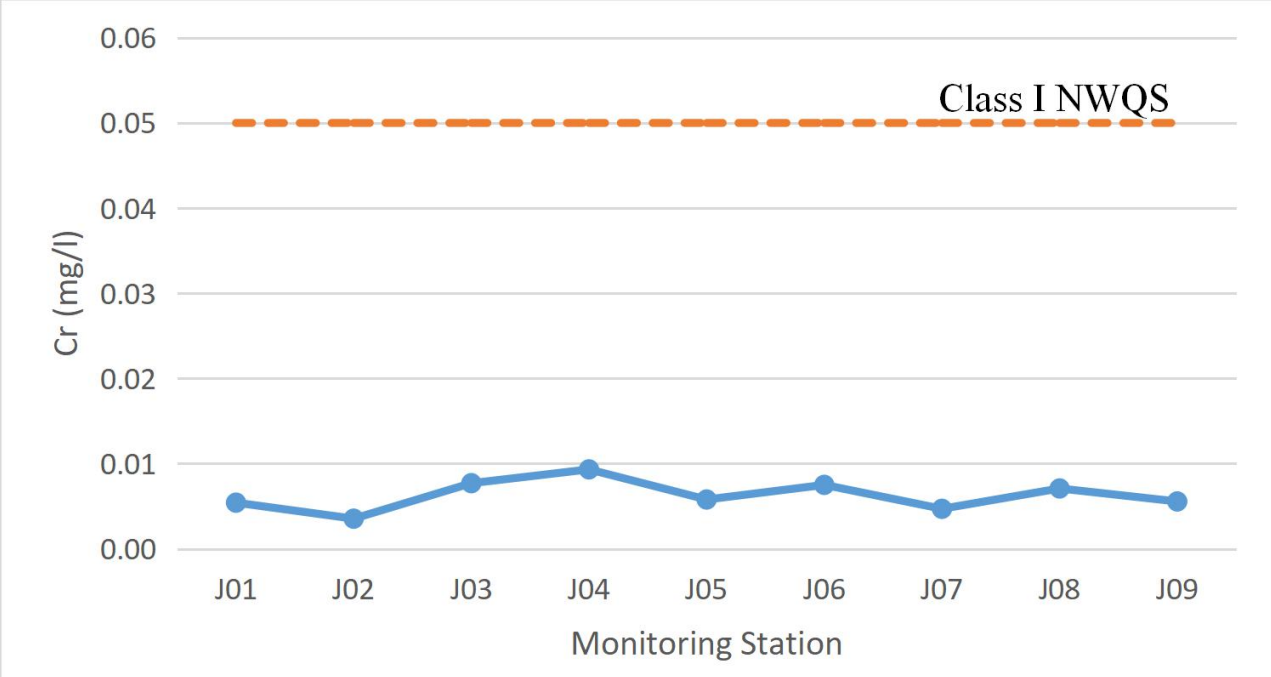


2h)

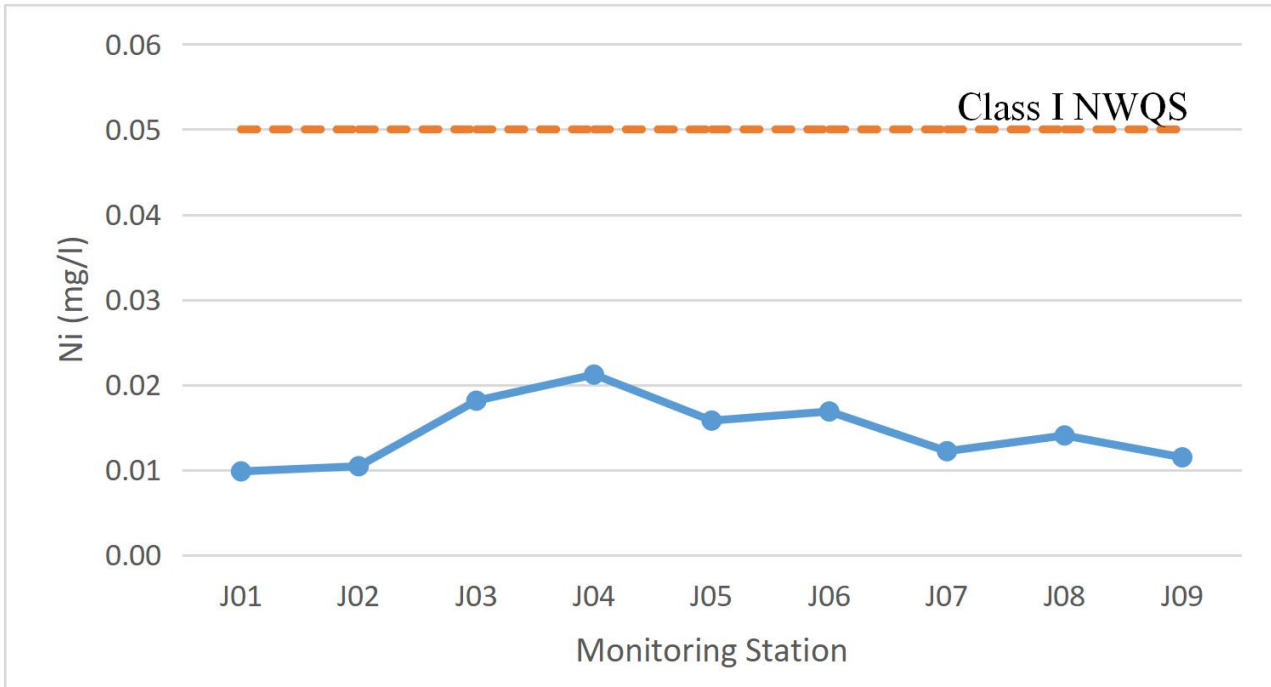

2i)

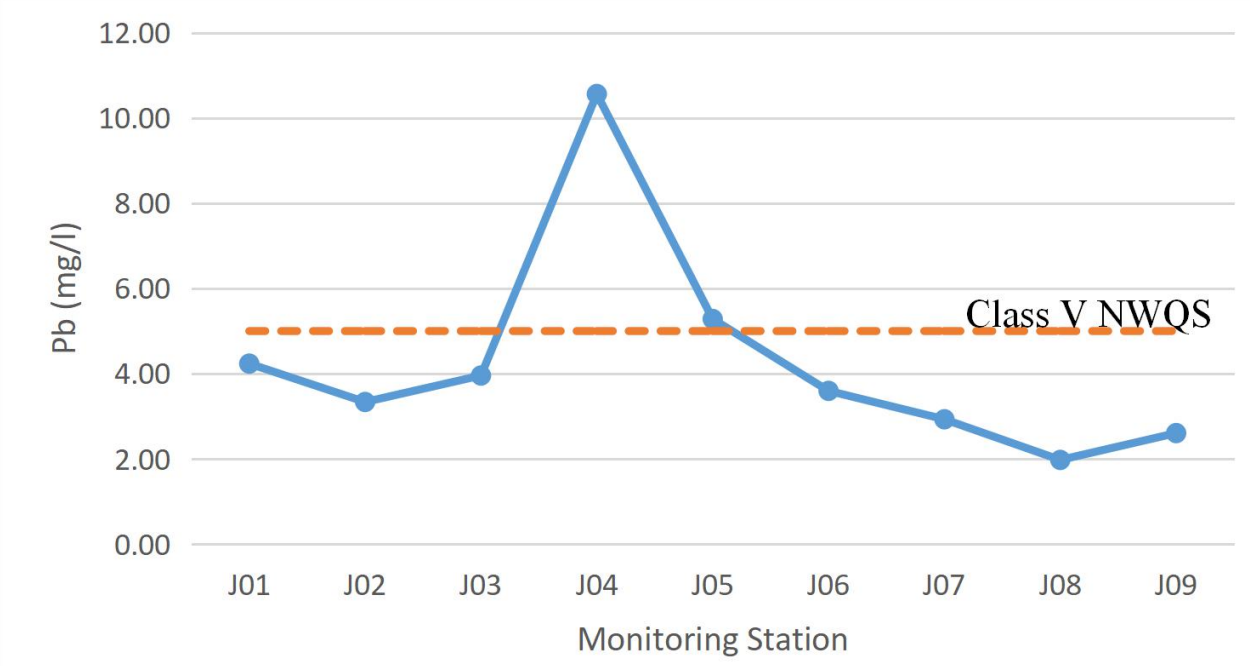

2j)

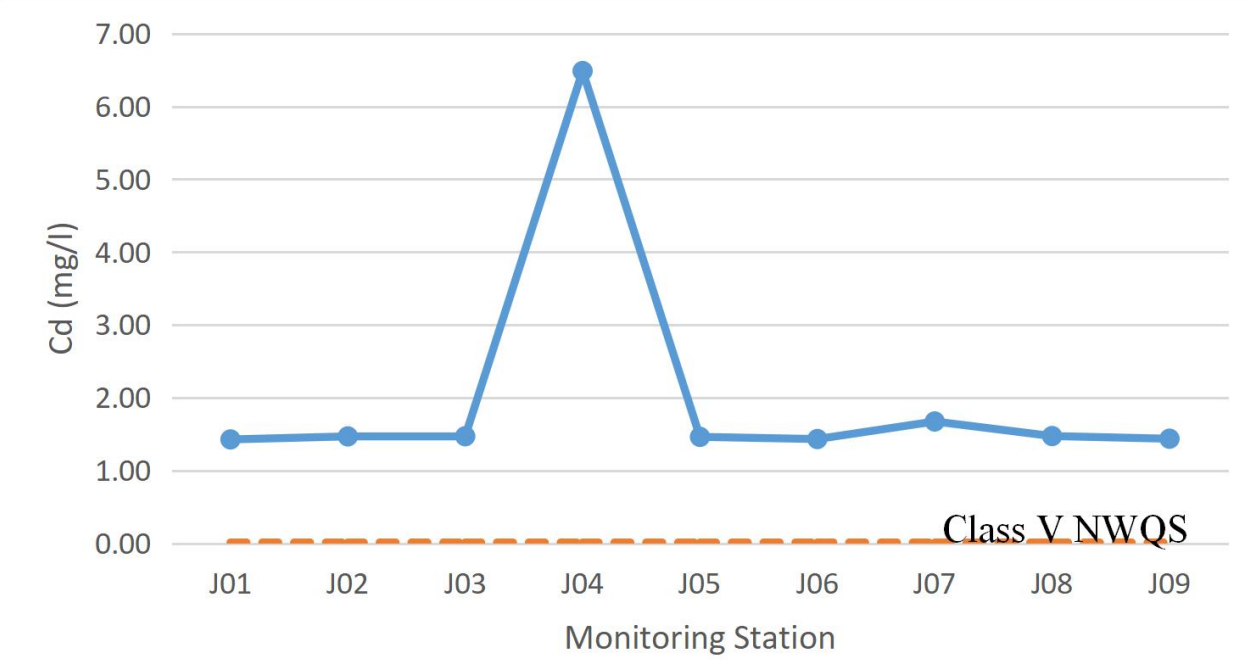

FIGURE 2. Average concentrations of heavy metals with below and higher than NWQS standard 


\section{OTHER HEAVY METAL ANALYSIS}

Because of their relentless and bioaccumulative nature, heavy metals are of huge concern and may pose possible environmental toxic effects, influx and perseverance (Abraham \& Susan 2017; Islam et al. 2017). In aquatic flora and fauna, heavy metals can accrue which can invade the human food chain and lead to health problems (Islam et al. 2017). Some heavy metals are vital for biological processes in the human body and act as both systemic and catalytic components of proteins and enzymes (Chen et al. 2018). A wide variety of natural and anthropogenic sources, including industrial, agricultural and domestic waste, release heavy metals into the environment (Jeelani et al. 2017; Xia et al. 2018).

For the detailed heavy metal analysis of $\mathrm{Sg}$. Sembilang water, Cadmium (Cd), Cromium (Cr), Magnesium $(\mathrm{Mg})$, Nickel $(\mathrm{Ni})$ and Lead $(\mathrm{Pb})$ were analyzed in the laboratory. From the analysis, it shows that these heavy metals were found in less concentration through the time being of the sampling in Sg. Sembilang from upstream to downstream stations. Table 2 shows the percentage of the other heavy metals affected in $\mathrm{Sg}$. Sembilang due to the different sources of pollutions. It was observed that the concentration of metals $(\mathrm{Cd}, \mathrm{Cr}$, $\mathrm{Pb}, \mathrm{Mg}$ and $\mathrm{Ni}$ ) is below permissible limit of NWQS. The concentrations were characterized by range of $\mathrm{Cd}$ (0.0014 - $0.005 \mathrm{mg} / \mathrm{L}), \mathrm{Cr}(0.0035-0.012 \mathrm{mg} / \mathrm{L}), \mathrm{Pb}$ $(0.002-0.019 \mathrm{mg} / \mathrm{L}), \mathrm{Mg}(0.0076-0.0193 \mathrm{mg} / \mathrm{L})$ and $\mathrm{Ni}(0.0076-0.019 \mathrm{mg} / \mathrm{L})$.

$\mathrm{Cd}$ concentration in water samples from $\mathrm{Sg}$. Sembilang ranged from 0.001 to $0.002 \mathrm{mg} / \mathrm{L}$ in stations $\mathrm{J} 01$ and J03, respectively. On average, Cd concentrations in all ten water samples were $0.0018 \pm 0.0011 \mathrm{mg} / \mathrm{L}$ (Table 2 ), therefore, the concentration of $\mathrm{Cd}$ in water was below the acceptable limit of $0.001 \mathrm{mg} / \mathrm{L}$ of NWQS. Common environmental sources of $\mathrm{Cd}$ include mining, smelting, fossil fuel burning, municipal waste incineration, $\mathrm{Ni}$ $\mathrm{Cd}$ batteries and varied industrial processes (Singh \& Kumar 2017). Greater concentration of Cd in J04 may have been demonstrated due to contiguity with dissolved rock and minerals and also sources of agriculture. Furthermore, the use of fertilizers, disposal of sewage sludge and deposition of atmospheric aerosol are key drivers of $\mathrm{Cd}$ in this area.

The existence of lead $(\mathrm{Pb})$ in the environment is deemed pollution as compared to anthropogenic activities, $\mathrm{Pb}$ from the natural source proves to be small (Singh \& Kumar 2017). In the present study, concentration of $\mathrm{Pb}$ varied from $0.002-0.019 \mathrm{mg} / \mathrm{L}$ with mean $\pm \mathrm{SD}$ value of $0.0045 \pm 0.0025 \mathrm{mg} / \mathrm{L}$. All studied samples were found less than the NWQS suggested allowable limit. $\mathrm{Pb}$ pollution thru the river can be caused by anthropogenic soil activity enrichment. At J04, the highest mean $\mathrm{Pb}$ concentration was observed. The misuses of palm oil plantation pesticides in this area are key contributors to the river's $\mathrm{Pb}$ water pollution.

$\mathrm{Ni}$ is a water - soluble heavy metal that originates in the water column from hydro - geochemical processes and anthropogenic actions. Neither industrial waste, crude oil plants, color plants, glass and ceramic industries and rejected batteries are important origin of $\mathrm{Ni}$ pollution (Sakai et al. 2017; Singh \& Kumar 2017). In the present study, Ni varied from $0.0076-0.019 \mathrm{mg} / \mathrm{L}$ with mean \pm SD value of $0.015 \pm 0.004 \mathrm{mg} / \mathrm{L}$. As stated by NWQS, all samples were found under the allowable limit $(0.9 \mathrm{mg} / \mathrm{L})$. Highest mean concentration of $\mathrm{Ni}$ was in downstream at site J02 and J04. Downstream of Sg. Sembilang lies within landfill and palm oil plantation, therefore, this could be the possible reasons of high concentration of $\mathrm{Ni}$ in downstream. As a result, the river could have held up as an effective agent for dispersing Ni from its source region (Singh \& Kumar 2017). Cr is a highly toxic metal, but the $\mathrm{Cr}$ concentration did not exceed the standard limit $(2.5 \mathrm{mg} / \mathrm{L})$ as recommended by NWQS in any sample. In the present study, $\mathrm{Cr}$ varied from $0.0035-0.012 \mathrm{mg} / \mathrm{L}$ with mean $\pm \mathrm{SD}$ value of 0.0069 $\pm 0.0025 \mathrm{mg} / \mathrm{L}$. Lowest mean concentration of $\mathrm{Cr}$ was found at $\mathrm{J} 02$.

Heavy metal pollution index is an appropriate tool to identify the surface water pollution as it integrates various parameters to appear at exact amount that can be correlated with the crucial amount to determine the amount of pollution capacity. The mean values of the preferred metals are taken into account in order to determine the HPI of the water. Table 3 details the calculations of HPI with standard permissible value. The HPI value for $\mathrm{Sg}$. Sembilang was below the critical value of 100, 6.05 (Table 3). For each sampling location, HPI was also measured separately to examine the pollution load and evaluate the water quality of the preferred areas. Considering the classes put forward the highest value of HPI was found in location J03 and was 7.989 lower from the critical value of 100 .

TABLE 3. HPI calculation for surface water sample

\begin{tabular}{llcc}
\hline \multicolumn{1}{c}{ Metals } & \multicolumn{1}{c}{$\begin{array}{c}\text { Mean } \\
\left(\mu \mathrm{g} . \mathrm{l}^{1}\right)\end{array}$} & $\begin{array}{c}\text { Highest Permissible } \\
\text { value }\left(\mu \mathrm{g} . \mathrm{l}^{1}\right)\end{array}$ & HPI \\
\hline Iron(Fe) & 3009.78 & 1000 & 0.30 \\
Magnesium(Mg) & 16678.30 & 150000 & 0.00 \\
Manganese(Mn) & 677.77 & 200 & 1.69 \\
Zinc(Zn) & 288.45 & 2000 & 0.01 \\
Aluminium $(\mathrm{Al})$ & 5861.88 & 500 & 2.34 \\
Cadmium(Cd) & 1.53 & 10 & 1.53 \\
Chromium(Cr) & 6.86 & 100 & 0.07 \\
Copper(Cu) & 26.74 & 200 & 0.07 \\
Lead(Pb) & 4.41 & 5000 & 0.00 \\
Nickel(Ni) & 15.02 & 200 & 0.04 \\
Total & & & 6.05 \\
\hline
\end{tabular}


Sampling stations J01 (HPI-5.4148); J02 (HPI- 5.794); J04 (HPI- 7.668); J05 (HPI- 6.020); J06 (HPI-6.182); J07 (HPI-5.173); J08 (HPI-4.862) and J09 (HPI-4.350) water quality with classify to metals, fall in the lower class $($ HPI $<15)$. The lowest HPI value was found in J09. In regard to the risky metallic pollution of river, the river water quality is considered to have low and moderate heavy metal pollution. Precautions must be taken into consideration where agricultural activities, industrial waste water, as well as landfill effluent discharge into the river are observed. Excessive usage of river water for agriculture, industrial, and recreational purposes are among the most significant reasons that make the river monitoring implantation inevitable.

\section{CONCLUSION}

In this study, the water sample of Sg. Sembilang was analyzed to assess the levels of heavy metals in river water. Concentration of $\mathrm{Al}, \mathrm{Fe}, \mathrm{Mn}, \mathrm{Mg}, \mathrm{Zn}, \mathrm{Cu}, \mathrm{Cd}, \mathrm{Pb}$, $\mathrm{Ni}$, and $\mathrm{Cr}$ were studied. It was found that $\mathrm{Al}$ and $\mathrm{Mn}$ were higher than the permissible values in the standard. The data gathered at the stations located within the upstream of the river ( 0101 and $\mathrm{J} 02$ ) shows low risk potentials while the data from the downstream stations (J03 to J09) proves to hold higher risk potentials. The main sources are landfill effluent, agricultural runoff, as well as industrial wastewater discharge to the river in downstream. However, the results show no statistical correlation among the behavior of different metals in water column alongside the river, which may be attributed to their same entry source. Calculated HPI based on the mean concentration of heavy metals, was found to be 6.05 that is below the critical pollution index value of 100 . With respect to sampling locations, station J03 registered the highest value of 7.989. This is probably due to the location of J03 which is very near to the effluent discharge point. The finding shows that the selected water samples from the river are polluted with regard to heavy metals. This analysis indicates the present scenario of water quality of Sg. Sembilang because of effluent from the landfill, material and waste water from industry, agricultural runoff and residential area. It also shows the varying dispersion of heavy metals concentrations among the sampling stations. This study has shown that significant parameters that contribute to the quality of water along the river include natural pollutants and anthropogenic pollutants. In addition, multivariate analysis applications can be used as a potential application for water quality studies of other tropical rivers having the same variation of seasons and pollutant sources as the study area. Thus, the present study reveals that there is an association of water quality studies with environmental management that can be used as a practical relevance for the study of environmental impacts on water ecosystems. This study can be used as a guide to new studies and water quality management studies such as water management for aquafarming, water security, ecological impact assessment, and catchment planning.

\section{ACKNOWLEDGEMENTS}

The authors would like to acknowledge the University of Malaya Research Grant (FL001-13SUS, GPF070A-2018) for the financial support. We would also like to thank the relevant authorities and companies who have contributed and assisted throughout the study period. We are most grateful and would like to thank the reviewers for their valuable suggestions, which have led to substantial improvement of the article.

\section{REFERENCES}

Abraham, M.R. \& Susan, T.B. 2017. Water contamination with heavy metals and trace elements from Kilembe copper mine and tailing sites in Western Uganda: Implications for domestic water quality. Chemosphere 169: 281-287.

Affandi, F.A. \& Ishak, M.Y. 2018. Heavy metal concentrations in tin mine effluents in Kepayang River, Perak, Malaysia. Journal of Physical Science 29(3): 81-86.

Aghoghovwia, O.A., Miri, F.A. \& Izah, S.C. 2018. Impacts of Anthropogenic activities on heavy metal levels in surface water of Nun River around Gbarantoru and Tombia Towns, Bayelsa State, Nigeria. Annals of Ecology and Environmental Science 2(2): 1-8.

Ali, M.M., Ali, M.L., Islam, M.S. \& Rahman, M.Z. 2016. Preliminary assessment of heavy metals in water and sediment of Karnaphuli River, Bangladesh. Environmental Nanotechnology, Monitoring \& Management 5: 27-35.

Amorosi, A. 2012. Chromium and nickel as indicators of sourceto-sink sediment transfer in a Holocene alluvial and coastal system (Po Plain, Italy). Sedimentary Geology 280: 260-269.

Angel, B.M., Apte, S.C., Batley, G.E. \& Golding, L.A. 2015. Geochemical controls on aluminium concentrations in coastal waters. Environmental Chemistry 13(1): 111-118.

Ayandiran, T.A., Fawole, O.O. \& Dahunsi, S.O. 2018. Water quality assessment of bitumen polluted Oluwa River, SouthWestern Nigeria. Water Resources and Industry 19: 13-24.

Bhuyan, M.S., Bakar, M.A., Akhtar, A., Belal Hossain, M., Ali, M.M. \& Islam, M.S. 2017. Heavy metal contamination in surface water and sediment of the Meghna River, Bangladesh. Environmental Nanotechnology, Monitoring \& Management 8: 273-279.

Borah, R., Taki, K., Gogoi, A., Das, P. \& Kumar, M. 2018. Contemporary distribution and impending mobility of arsenic, copper and zinc in a tropical (Brahmaputra) river bed sediments, Assam, India. Ecotoxicology and Environmental Safety 161: 769-776.

Bui, T.K.L., Do-Hong, L.C., Dao, T.S. \& Hoang, T.C. 2016. Copper toxicity and the influence of water quality of Dongnai River and Mekong River waters on copper bioavailability and toxicity to three tropical species. Chemosphere 144: 872-878.

Bukar, P.H., Oladlpo, M.O.A., Ibeanu, I.G.E. \& Zakari, I.Y. 2016. Assessment and distribution of metal pollutants in the water of River Ngadda and Alau Dam used for irrigation farming in Maiduguri, Borno State, Nigeria. American Journal of Research Communication 4(4): 74-84.

Chai, H.P., Lee, N., Grinang, J., Ling, T.Y. \& Sim, S.F. 2018. Assessment of heavy metals in water, fish and sediments of the Baleh River, Sarawak, Malaysia. Borneo Journal of Resource Science and Technology 8(1): 30-40.

Chen, L., Zhou, S., Shi, Y., Wang, C., Li, B., Li, Y. \& Wu, S. 2018. Heavy metals in food crops, soil, and water in the 
Lihe River Watershed of the Taihu Region and their potential health risks when ingested. Science of the Total Environment 615: 141-149.

Duan, W., He, B., Nover, D., Yang, G., Chen, W., Meng, H., Zhou, S. \& Liu, C. 2016. Water quality assessment and pollution source identification of the eastern Poyang Lake Basin using multivariate statistical methods. Sustainability 8(2): 133. https://doi.org/10.3390/su8020133.

Essington, M.E. 2015. Soil and Water Chemistry: An Integrative Approach. 2nd ed. Boca Raton: CRC Press.

Fawaz Al-Badaii, Azhar Abdul Halim \& Mohammad ShuhaimiOthman. 2016. Evaluation of dissolved heavy metals in water of the Sungai Semenyih (Peninsular Malaysia) using environmetric methods. Sains Malaysiana 45(6): 841-852.

Frémion, F., Courtin-Nomade, A., Bordas, F., Lenain, J.F., Jugé, P., Kestens, T. \& Mourier, B. 2016. Impact of sediments resuspension on metal solubilization and water quality during recurrent reservoir sluicing management. Science of the Total Environment 562: 201-215.

Gafur, N., Sakakibara, M., Sano, S. \& Sera, K. 2018. A case study of heavy metal pollution in water of Bone River by artisanal small-scale gold mine activities in Eastern Part of Gorontalo, Indonesia. Water 10(11): 1507.

Gao, Z. 2018. Evaluation of heavy metal pollution and its ecological risk in one river reach of a gold mine in Inner Mongolia, Northern China. International Biodeterioration \& Biodegradation 128: 94-99.

Gozzard, E., Mayes, W.M., Potter, H.A.B. \& Jarvis, A.P. 2011. Seasonal and spatial variation of diffuse (non-point) source zinc pollution in a historically metal mined river catchment, UK. Environmental Pollution 159(10): 3113-3122.

Guinoiseau, D., Bouchez, J., Gélabert, A., Louvat, P., MoreiraTurcq, P., Filizola, N. \& Benedetti, M.F. 2018. Fate of particulate copper and zinc isotopes at the Solimões-Negro river confluence, Amazon Basin, Brazil. Chemical Geology 489: 1-15.

Harguinteguy, C.A., Noelia Cofre, M., Fernandez-Cireli, A. \& Luisa Pignata, M. 2016. The macrophytes Potamogeton pusillus L. and Myriophyllum aquaticum (Vell.) Verdc. As potential bioindicators of a river contaminated by heavy metals. Microchemical Journal 124: 228-234.

Irzon, R., Syafri, I., Hutabarat, J., Sendjaja, P. \& Permanadewi, S. 2018. Heavy metals content and pollution in tin tailings from Singkep Island, Riau, Indonesia. Sains Malaysiana 47(11): 2609-2616.

Ismail, S.N.S. \& Manaf, L.A. 2013. The challenge of future landfill: A case study of Malaysia. Journal of Toxicology and Environmental Health Sciences 5(6): 86-96.

Islam, M.A., Al-Mamun, A., Hossain, F., Quraishi, S.B., Naher, K., Khan, R. \& Nahid, F. 2017. Contamination and ecological risk assessment of trace elements in sediments of the rivers of Sundarban mangrove forest, Bangladesh. Marine Pollution Bulletin 124(1): 356-366.

Jeelani, N., Zhu, Z., Wang, P., Zhang, P., Song, S., Yuan, H., An, S. \& Leng, X. 2017. Assessment of trace metal contamination and accumulation in sediment and plants of the Suoxu River, China. Aquatic Botany 140: 92-95.

Kändler, M., Blechinger, K., Seidler, C., Pavlů, V., Šanda, M., Dostál, T., Krása, J., Vitvar, T. \& Štich, M. 2017. Impact of land use on water quality in the upper Nisa catchment in the Czech Republic and in Germany. Science of the Total Environment 586: 1316-1325.

Kadhum, S.A., Ishak, M.Y., Zulkifli, S.Z. \& binti Hashim, R. 2015. Evaluation of the status and distributions of heavy metal pollution in surface sediments of the Langat River Basin in Selangor, Malaysia. Marine Pollution Bulletin 101(1): 391-396.

Khalaf, B., Abdullah, M.P. \& Tahrim, N.A. 2018. Detection of heavy metals in water in Negeri Sembilan, Malaysia: From source to consumption. AIP Conference Proceedings 1940(1): 020107.

Majhi, A. \& Biswal, S.K. 2016. Application of HPI (Heavy Metal Pollution Index) and correlation coefficient for the assessment of ground water quality near ash ponds of thermal power plants. International Journal of Science Engineering and Advance Technology 4(8): 395-405.

Meng, Q., Chen, H., Lin, J., Lin, Z. \& Sun, J. 2017. Zeolite A synthesized from alkaline assisted pre-activated halloysite for efficient heavy metal removal in polluted river water and industrial wastewater. Journal of Environmental Sciences 56: 254-262

Naji, A., Ismail, A. \& Ismail, A.R. 2010. Chemical speciation and contamination assessment of $\mathrm{Zn}$ and $\mathrm{Cd}$ by sequential extraction in surface sediment of Klang River, Malaysia Microchemical Journal 95: 285-292.

Nguyen, T.T.H., Zhang, W., Li, Z., Li, J., Ge, C., Liu, J., Bai, X., Feng, H. \& Yu, L. 2016. Assessment of heavy metal pollution in Red River surface sediments, Vietnam. Marine Pollution Bulletin 113: 513-519.

Noulas, C., Tziouvalekas, M. \& Karyotis, T. 2018. Zinc in soils, water and food crops. Journal of Trace Elements in Medicine and Biology 49: 252-260.

Othman, F., Uddin Chowdhury, M., Jaafar, W., Zurina, W., Mohammad Faresh, E.M. \& Shirazi, S.M. 2018. Assessing risk and sources of heavy metals in a tropical river basin: A case study of the Selangor River, Malaysia. Polish Journal of Environmental Studies 27(4): 1659-1671.

Panfili, I., Bartucca, M.L., Ballerini, E. \& Buono, D.D. 2017. Combination of aquatic species and safeners improves the remediation of copper polluted water. Science of the Total Environment 601-602: 1263-1270.

Paul, D. 2017. Research on heavy metal pollution of river Ganga: A review. Annals of Agrarian Science 15(2): 278-286.

Pfeiffer, M., Batbayar, G., Hofmann, J., Siegfried, K., Karthe, D. \& Hahn-Tomer, S. 2015. Investigating arsenic (As) occurrence and sources in ground, surface, waste and drinking water in Northern Mongolia. Environmental Earth Sciences 73(2): 649-662.

Rahmanian, N., Ali, S.H.B., Homayoonfard, M., Ali, N.J., Rehan, M., Sadef, Y. \& Nizami, A.S. 2015. Analysis of physiochemical parameters to evaluate the drinking water quality in the State of Perak, Malaysia. Journal of Chemistry 2015: 716125.

Rajeshkumar, S., Liu, Y., Zhang, X., Ravikumar, B. \& Bai, G. 2018. Studies on seasonal pollution of heavy metals in water, sediment, fish and oyster from the Meiliang Bay of Taihu Lake in China. Chemosphere 191: 626-638.

Rosli, M.N.R., Samat, S.B., Yasir, M.S. \& Yusof, M.F.M 2018. Analysis of heavy metal accumulation in fish at Terengganu Coastal Area, Malaysia. Sains Malaysiana 47(6): 1277-1283.

Sakai, N., Alsaad, Z., Thuong, N.T., Shiota, K., Yoneda, M. \& Mohd, M.A. 2017. Source profiling of arsenic and heavy metals in the Selangor River basin and their maternal and cord blood levels in Selangor State, Malaysia. Chemosphere 184: 857-865.

Sarkar, A. \& Shekhar, S. 2018. Iron contamination in the waters of Upper Yamuna basin. Groundwater for Sustainable Development 7: 421-429. 
Shaari, H., Raven, B., Sultan, K., Mohammad, Y. \& Yunus, K. 2016. Status of heavy metals concentrations in oysters (Crassostrea sp.) from Setiu Wetlands, Terengganu, Malaysia. Sains Malaysiana 45(3): 417-424.

Singh, U.K. \& Kumar, B. 2017. Pathways of heavy metals contamination and associated human health risk in Ajay River basin, India. Chemosphere 174: 183-199.

Sukri, N.S., Aspin, S.A., Kamarulzaman, N.L., Jaafar, N.F., Ghazi, R.M., Shafiee, N.S., Siti Hajar Yaacob, Farah Khaliz Kedria. \& Zakaria, M.P. 2018. Assessment of metal pollution using enrichment factor (EF) and pollution load index (PLI) in sediments of selected Terengganu Rivers, Malaysia. Malaysian Journal of Fundamental and Applied Sciences 14(2): 235-240.

Superville, P.J., Ivanovsky, A., Bhurtun, P., Prygiel, J. \& Billon, G. 2018. Diel cycles of reduced managenese and their seasonal variability in the Marque River (Northern France). Science of the Total Environment 624: 918-925.

Sutela, T. \& Vehanen, T. 2017. The effects of acidity and aluminium leached from acid-sulphate soils on riverine fish assemblages. Boreal Environment Research 22: 385-391.

Tang, W., Duan, S., Shan, B., Zhang, H., Zhang, W., Zhao, Y. \& Zhang, C. 2016. Concentrations, diffusive fluxes and toxicity of heavy metals in pore water of the Fuyang River, Haihe Basin. Ecotoxicology and Environmental Safety 127: 80-86.

Tair, R. \& Eduin, S. 2018. Heavy metals in water and sediment from Liwagu River and Mansahaban River at Ranau Sabah. Malaysian Journal of Geosciences (MJG) 2(2): 26-32.

United States Environmental Protection Agency, Method 200.8. 1994. Determination of trace elements in waters and wastes by inductively coupled plasma-Mass Spectrometry.

Xia, F., Qu, L., Wang, T., Luo, L., Chen, H., Dahlgren, R.A., Zhang, M., Mei, K. \& Huang, H. 2018. Distribution and source analysis of heavy metal pollutants in sediments of a rapid developing urban river system. Chemosphere 207: 218-228.

Xu, F., Liu, Z., Cao, Y., Qju, L., Feng, J., Xu, F. \& Tian, X. 2017. Assessment of heavy metal contamination in urban river sediments in the Jiaozhou Bay catchment, Qingdao, China. Catena 150: 9-16.

Xu, L., Wang, T., Wang, J. \& Lu, A. 2017. Occurrence, speciation and transportation of heavy metals in 9 coastal rivers from watershed of Laizhou Bay, China. Chemosphere 173: 61-68.

Wang, Y.B., Liu, C.W., Liao, P.Y. \& Lee, J.J. 2013. Spatial pattern assessment of river water quality: Implications of reducing the number of monitoring stations and chemical parameters. Environmental Monitoring Assessment 186(3): 1781-1792.

Wang, J., Liu, G., Liu, H. \& Lam, P.K.S. 2017. Multivariate statistical evaluation of dissolved trace elements and a water quality assessment in the middle reaches of Huaihe River, Anhui, China. Science of the Total Environment 583: 421-431.
Wu, Q., Zhou, H., Tam, N.F.Y., Tian, Y., Tan, Y., Zhou, S., Li, Q., Chen, Y. \& Leung, J.Y.S. 2016. Contamination, toxicity and speciation of heavy metals in an industrialized urban river: Implications for the dispersal of heavy metals. Marine Pollution Bulletin 104: 153-161.

Wu, S.S., Yang, H., Guo, F. \& Han, R.M. 2017. Spatial patterns and origins of heavy metals in Sheyang River catchment in Jiangsu, China based on geographically weighted regression. Science of the Total Environment 580: 1518-1529.

Zhang, G., Bai, J., Zhao, Q., Lu, Q., Jia, J. \& Wen, X. 2016. Heavy metals in wetland soils along a wetland-forming chronosequence in the Yellow River Delta of China: Levels, sources and toxic risks. Ecological Indicators 69: 331-339.

Zhang, Z., Wang, J.J., Ali, A. \& DeLaune, R.D. 2018. Physicochemical forms of copper in water and sediments of Lake Pontchartrain basin, USA. Chemosphere 195: 448-454.

Zhao, X.M., Yao, L.A., Ma, Q.L., Zhou, G.J., Wang, L., Fang, Q.L. \& Xu, Z.C. 2018. Distribution and ecological risk assessment of cadmium in water and sediment in Longjiang River, China: Implication on water quality management after pollution accident. Chemosphere 194: 107-116.

Zuziak, J. \& Jakubowska, M. 2017. Voltammetric determination of aluminum-Alizarin $\mathrm{S}$ complex by renewable silver amalgam electrode in river and waste waters. Journal of Electroanalytical Chemistry 794: 49-57.

Tengku Nilam Baizura Tengku Ibrahim Institute of Biological Science

Faculty of Science

University of Malaya

50603, Kuala Lumpur, Federal Territory

Malaysia

Faridah Othman*

Department of Civil Engineering

Faculty of Engineering

University of Malaya

50603, Kuala Lumpur, Federal Territory

Malaysia

Noor Zalina Mahmood

Department of Environmental Health

Faculty of Health and Sport Sciences

MAHSA University

42610, Selangor Darul Ehsan

Malaysia

*Corresponding author; email: faridahothman@um.edu.my

Received: 17 March 2019

Accepted: 1 January 2020 